\title{
Enhancement of clover growth by inoculation of P-solubilizing fungi and arbuscular mycorrhizal fungi
}

\author{
EDSON L. SOUCHIE ${ }^{1}$, ROSARIO AZCÓN ${ }^{2}$, JOSE M. BAREA ${ }^{2}$, ELIANE M.R. SILVA ${ }^{3}$ \\ and ORIVALDO J. SAGGIN-JÚNIOR ${ }^{3}$ \\ ${ }^{1}$ Instituto Federal de Educação, Ciência e Tecnologia Goiano - Campus Rio Verde \\ Caixa Postal 66, 75901-970 Rio Verde, GO, Brasil \\ ${ }^{2}$ Estación Experimental del Zaidín, Dep. de Microbiología y Sistemas Simbióticos \\ Calle Prof. Albareda 1, 18008 Granada, España \\ ${ }^{3}$ Embrapa Agrobiologia, Caixa Postal 101, 23890-970 Seropédica, RJ, Brasil \\ Manuscript received on May 17, 2009; accepted for publication on February 15, 2010
}

\begin{abstract}
This study evaluated the synergism between several P-solubilizing fungi isolates and arbuscular mycorrhizal fungi to improve clover (Trifolium pratense) growth in the presence of Araxá apatite. Clover was sown directly in plastic pots with $300 \mathrm{~g}$ of sterilized washed sand, vermiculite and sepiolite 1:1:1 (v:v:v) as substrate, and grown in a controlled environment chamber. The substrate was fertilized with $3 \mathrm{~g} \mathrm{~L}^{-1}$ of Araxá apatite. A completely randomized design, in $8 \times 2$ factorial scheme (eight P-solubilizing fungi treatments with or without arbuscular mycorrhizal fungi) and four replicates were used. The P-solubilizing fungi treatments consisted of five Brazilian P-solubilizing fungi isolates (PSF 7, 9, 20, 21 and 22), two Spanish isolates (Aspergillus niger and the yeast Yarowia lipolytica) and control (non-inoculated treatment). The greatest clover growth rate was recorded when Aspergillus niger and PSF 21 were co-inoculated with arbuscular mycorrhizal fungi. Aspergillus niger, PSF 7 and PSF 21 were the most effective isolates on increasing clover growth in the presence of arbuscular mycorrhizal fungi. Greater mycorrhizal colonization resulted in greater clover growth rate in most PSF treatments. PSF 7 was the best isolate to improve the establishment of mycorrhizal and rhizobia symbiosis.
\end{abstract}

Key words: Araxá apatite, phosphate solubilization, co-inoculation, plant growth promotion, rhizosphere.

\section{INTRODUCTION}

Soil microorganisms play an important role in supplying nutrients to plants. Phosphorus (P) is the least mobile and available to plants in most soil conditions, in comparison to other major nutrients (El-Azouni 2008). Nevertheless, some microorganisms are able of mineralizing and solubilizing $\mathrm{P}$ from the organic and inorganic soil pools (Richardson 2001). Souchie et al. (2006) stated that $\mathrm{P}$ is the most limiting nutrient in tropical soils; in contrast, P-solubilizing microorganisms (PSM) and the arbuscular mycorrhizal fungi (AMF) are among the most relevant soil microorganisms.

Correspondence to: Edson Luiz Souchie

E-mail: esouchie@yahoo.com.br
The inoculation of PSM is a promising technique in order to increase $\mathrm{P}$ availability in soils fertilized with rock phosphates (Reyes et al. 2002). Several authors reported yield increases on maize (Reyes et al. 2002), sorghum (Kumar et al. 1999), and wheat (Whitelaw et al. 1997, Wahid and Mehana 2000) by inoculation of P-solubilizing fungi (PSF). Rodríguez et al. (1999) reported a greatest alfalfa growth in soil fertilized with rock phosphate and sugar beet waste through inoculation of Aspergillus niger (an isolate with high $\mathrm{P}$ solubilization potential) and Glomus deserticola. The synergism between these microorganisms also promoted considerable increases in $\mathrm{P}$ absorption and growth in clover (Trifolium repens) (Vassileva et al. 1998). Similarly, the 
co-inoculation of Yarowia lipolytica (a P-solubilizing yeast) increased mycorrhizal colonization by Glomus deserticola in tomato roots (Vassilev et al. 2001). Ravnskov et al. (1999) also observed mycorrhizal colonization increasing forage leguminous roots after the inoculation of Saccharomyces cerevisiae. Nowadays, it is widely accepted that several PSM, besides solubilizing $\mathrm{P}$, also increase mycorrhizal colonization, produce vitamins, amino acids and phytohormones (Barea et al. 1997, Arshad and Frankenberger Jr. 1998). Therefore, more studies to establish the functional compatibility among these microorganisms on improving plant growth of several species are required.

The PSF efficiency changes according to isolate and phosphate type (Souchie et al. 2005). Therefore, studies about $\mathrm{P}$ solubilization of rock phosphates in systems involving plants inoculated with PSM and AMF should be done. This study evaluated the synergism between several PSF and AMF isolates in improving clover growth fertilized with Araxá apatite.

\section{MATERIALS AND METHODS}

The experiment was done at Estación Experimental del Zaidín, Granada, Spain, in a controlled environment chamber. Clover (Trifolium pratense) was sown in plastic pots containing $300 \mathrm{~g}$ of substrate (washed sand, vermiculite and sepiolite, 1:1:1, v:v:v). Each component was autoclaved $\left(120^{\circ} \mathrm{C}, 20 \mathrm{~min}\right)$ separately. Araxá apatite $\left(12 \mathrm{~g}\right.$ of $\left.\mathrm{P} \mathrm{kg}^{-1}\right)$ was mixed to the substrate at $3 \mathrm{~g} \mathrm{~L}^{-1}$.

A completely randomized design, in $8 \times 2$ factorial scheme (eight inoculation treatments and presence or absence of AMF) and four replicates were used. The inoculation treatments were: 1) control (non-inoculated); 2) PSF 7; 3) PSF 9; 4) PSF 20; 5) PSF 21; 6) PSF 22; 7) Aspergillus niger and 8) Yarowia lipolytica. The isolates Aspergillus niger and Yarowia lipolytica belong to the Estación Experimental del Zaidín collection and are considered to be isolates with high P-solubilization potential (Vassileva et al. 1998, 2000). PSF 7 and 9 were isolated from the rhizosphere of Mimosa caesalpiniifolia grown in an Argisol collected at an Atlantic Forest area in Paraty, Rio de Janeiro, Brazil. PSF 20, 21 and 22 were obtained from the rhizosphere of Acacia holosericea grown in Planosol collected at Seropédica, Rio de Janeiro, Brazil.
The mycorrhizal inoculum consisted of soil containing spores, mycelia and root fragments colonized by Glomus clarum and Glomus geosporum. Equal proportions were prepared by mixing $300 \mathrm{~mL}$ of soil containing 8 and 20 spores per $\mathrm{mL}^{-1}$ of soil of G. clarum and $G$. geosporum, respectively. Both AMF were multiplied in sorghum and maize trap plants and maintained as a stock culture. Prior to sowing, an amount of $5 \mathrm{~mL}$ of inoculum was added to each pot and homogenized with the substrate. In the control, $2 \mathrm{~mL}$ of an inoculum filtrate, obtained by mixing $1 \mathrm{~mL}$ of both G. clarum and G. geosporum inoculum filtrates without AMF propagules, were added to the plant basis in each pot.

Four days after emergence, seedlings were thinned to one plant per pot. Each plant was inoculated with $1 \mathrm{~mL}$ of Rhizobium trifolii (strain 2152). This strain was incubated in Ty liquid medium (Beringer 1974), to $10^{8}$ CFU $\mathrm{mL}^{-1}$. Two days after $R$. trifolii inoculation, the plants were inoculated with PSF treatments. These PSF isolates were grown in Petri dishes (four days, $28^{\circ} \mathrm{C}$, darkness), with GL solid medium (Sylvester-Bradley et al. 1982) covering the Petri dish basis. Spores were suspended in water + tween $(1 \%)$ solution, quantified following the successive dilution technique till $10^{8} \mathrm{CFU}$ $\mathrm{mL}^{-1}$ and, subsequently, $1 \mathrm{~mL}$ of spore suspension was applied to each pot.

The experiment lasted 60 days in a controlled environment chamber with $50 \%$ relative humidity, day and night temperature of 27 and $18^{\circ} \mathrm{C}$, respectively, and a photoperiod of 14 hours, with photosynthetic photon flux density of $503 \mu \mathrm{mol} \mathrm{m} \mathrm{m}^{2}$. Twice a week, $25 \mathrm{~mL}$ of a modified nutrient solution (Hewitt 1966) (without $\mathrm{N}, 10 \%$ of $\mathrm{P}$ and $\mathrm{pH} 5.5$ ) were added to each pot.

Forty days after emergence, shoot dry matter was determined. Sixty days after emergence, plants were harvested and shoot dry matter, colonized root length (Tennant 1975, Giovannetti and Mosse 1980), number of nodules, N and P shoot contents were evaluated. Data were submitted to ANOVA and the averages compared by the $\mathrm{F}$ and Tukey tests $(p \leq 0.05)$.

\section{RESULTS}

AMF and PSF inoculation increased shoot dry matter in most treatments, except for plants inoculated with PSF 7, PSF 22 and Y. lipolytica (Fig. 1). PSF 7 and PSF 21 stimulated the greatest shoot dry matter pro- 


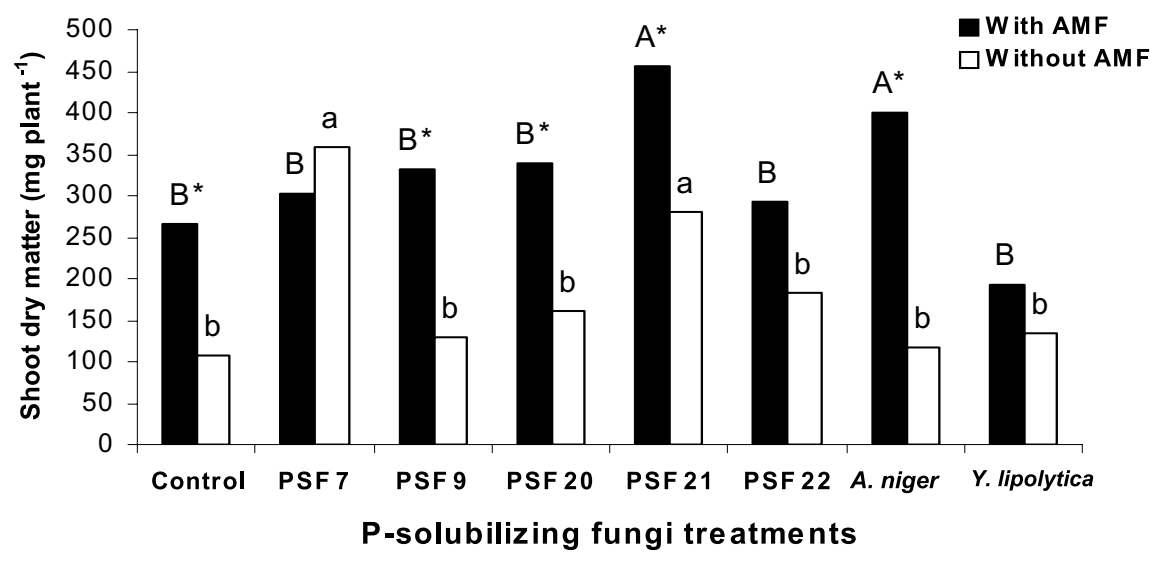

Fig. 1 - Shoot dry matter (two cuts) of clover inoculated with P-solubilizing fungi from Paraty, Rio de Janeiro, Brazil (PSF 7, 9, 20, 21 and 22) and from Granada, Spain (A. niger and Y. lipolytica), in the presence or absence of AMF. (Lower-case and upper-case letters compare PSF treatments in the absence and presence of AMF inoculation, respectively, by the Scott-Knott test $(p \leq 0.05) . *$ : indicates AMF effect by the F test $(p \leq 0.05)$.

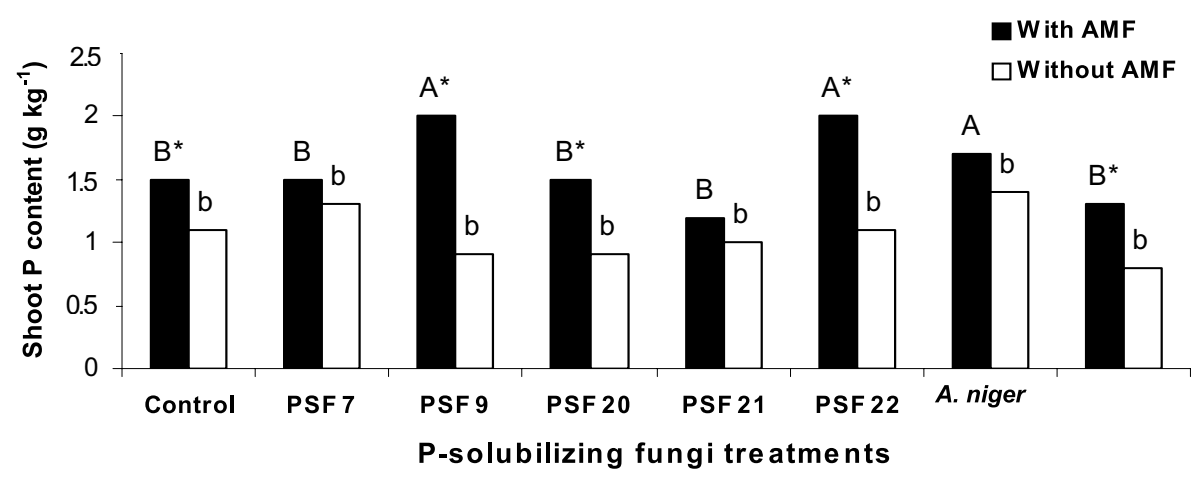

Fig. 2 - Shoot P content of clover inoculated with P-solubilizing fungi from Paraty, Rio de Janeiro, Brazil (PSF 7, 9, 20, 21 and 22) and from Granada, Spain (A. niger and Y. lipolytica), in the presence or absence of AMF. (Lower-case and upper-case letters compare PSF treatments in the absence and presence of AMF inoculation, respectively, by the Scott-Knott test $(p \leq 0.05)$.

*: indicates AMF effect by the F test $(p \leq 0.05)$.

duction in the absence of AMF. Aspergillus niger and PSF 21 with AMF inoculation were the best treatments to increase shoot dry matter. In contrast, plants inoculated with Y. lipolytica showed little shoot dry matter production both in the presence and in the absence of AMF (Fig. 1).

No interactions were observed between AMF and PSF when $\mathrm{N}$ shoot content was evaluated since AMF inoculation did not affect this parameter. The PSF inoculation yielded the greatest shoot $\mathrm{N}$ content $(3.2 \mathrm{~g} \mathrm{~N}$ $\left.\mathrm{kg}^{-1}\right)$, which was similar to the control $\left(3.1 \mathrm{~g} \mathrm{~N} \mathrm{~kg}^{-1}\right)$.
Similar values of shoot $\mathrm{P}$ content were found in plants inoculated or not with AMF in the presence of PSF 7, PSF 21 and A. niger (Fig. 2). AMF inoculation increased the shoot $\mathrm{P}$ content on the other treatments. No significant differences were found among plants inoculated with PSF, without AMF inoculation, and the control treatment (Fig. 2).

Although PSF 7 and PSF 21 increased the number of nodules in plants, AMF inoculation affected neither this parameter nor the interaction between PSF and AMF (Fig. 3). However, an enhancement on mycor- 
rhizal colonization was observed in plants inoculated with AMF in the presence of PSF 7 and PSF 20 (Fig. 4). The other treatments were similar to the control.

\section{DISCUSSION}

Since plants were grown in an inert substrate where a nutritive solution with low $\mathrm{P}$ concentration was periodically amended, PSF contribution on growth promotion was probably due to an effective Araxá apatite solubilization (Souchie et al. 2005) and/or by phytohormone production (Barea et al. 1997), or even to the increase of rhizobia and AMF symbiosis (Omar 1998, Zaidi et al. 2004). In the case of PSF 21, growth promotion can be related to greater nodulation or release of stimulating substances since this isolate did not increase AMF colonization. Similarly, Cabello et al. (2005) reported that mycorrhizal colonization in Mentha piperita was not affected by inoculation with the PSF Penicillium thomii, despite this isolate increased other analyzed variables. Zaidi et al. (2004) reported some incompatibility when Glomus fasciculatum, Bradyrhizobium sp. and Penicillium sp. were inoculated in mung bean without any improvement on plant growth. Otherwise, Valdenegro et al. (2001) reported that the inoculation of plant growth promoting rhizobacteria was effective only when Glomus mosseae and a native strain of Rhizobium meliloti were also inoculated. The success of the inoculation technique is directly related to the functional compatibility among the chosen microorganisms. Therefore, more research is required to discover the best combinations among them in order to increase nutrition and growth of plant species.

Yarowia lipolytica inoculation yielded similar results to the control treatment for almost all the analyzed variables. However, several authors (Vassileva et al. 2000, Vassilev et al. 2001, Medina et al. 2004) reported considerable improvement on plant growth with Y. lipolytica inoculation. Probably, in this study, the main limiting factor was the substrate since no source of organic matter was used. Consequently, the establishment of Y. lipolytica was negatively affected.

PSF 7 increased clover shoot dry matter in the absence of AMF similarly to plants inoculated with AMF (Fig. 1). Since this isolate is capable of solubilizing Araxá apatite in liquid medium, and aluminum phosphate in solid and liquid media (Souchie et al. 2005), it has probably greater solubilization ability in comparison to the other isolates. Moreover, PSF 7 was the one that stimulated the greatest nodulation and mycorrhizal colonization (Figs. 3 and 4). Reyes et al. (2002) also reported that all Penicillium rugulosum P-solubilizing strains were able to stimulate maize growth as indicated by 3.6 to $28.6 \%$ increases in dry matter yield. Peix et al. (2001) observed a greater number of nodules in common bean plants inoculated with a P-solubilizing Burkholderia cepacia strain. Similarly, Fracchia et al. (2004) reported an increased mycorrhizal colonization in soybean after inoculation with the PSF Aspergillus niger. Since biological nitrogen fixation depends on the available forms of phosphorus, the combined inoculation of nitrogen fixers, P-solubilizing microorganisms and AMF may benefit plant growth more than any organism group alone.

In this study, although all PSF isolates belonged to the Aspergillus genus, it is possible that PSF 7 is a different species, explaining its different effect on clover growth. Also, Nguyen et al. (1992) reported that the P solubilization ability can vary among microorganisms within the same species. Silva Filho et al. (2002) reported that the most efficient $\mathrm{P}$-solubilizing fungi belong to Aspergillus and Penicillium genera. Future research should be done to determine the organic acids released by these PSF, especially by PSF 7. Moreover, evaluation of the ability to improve plant growth and rhizobia and AMF symbiosis under non-sterilized substrate conditions should be done.

\section{CONCLUSIONS}

1 - Aspergillus niger, PSF 7 and PSF 21 were the best isolates to increase clover growth in the presence of AMF.

2 - High mycorrhizal colonization resulted in greater clover growth rate in most PSF treatments.

3 - The greatest clover growth rate was recorded when Aspergillus niger and PSF 21 were co-inoculated with AMF.

4 - The isolate PSF 7 was the best isolate to increase clover growth and to establish rhizobia and AMF symbiosis. 


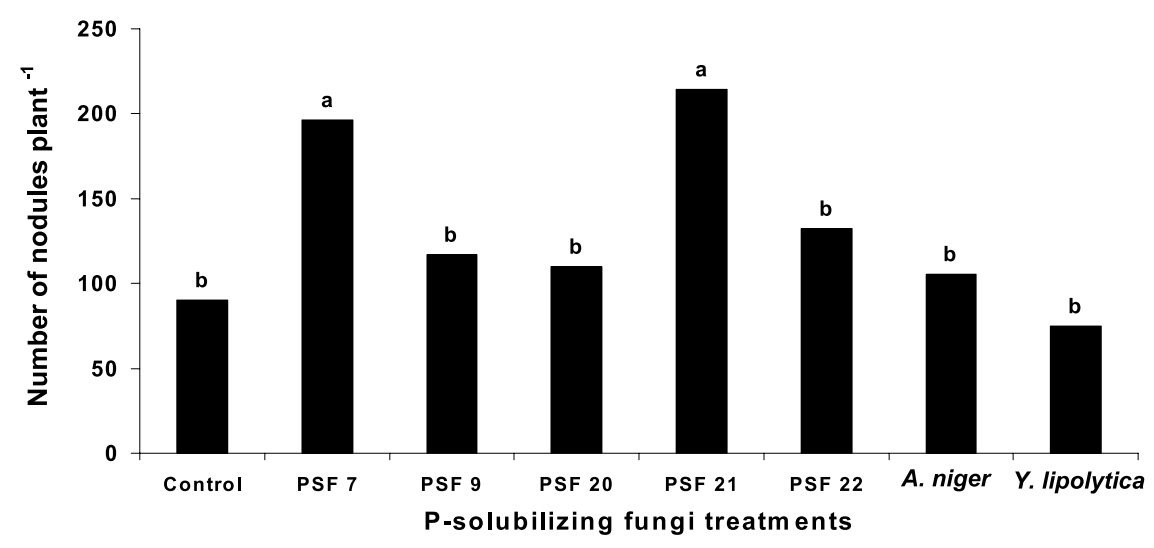

Fig. 3 - Number of Rhizobium nodules of clover inoculated with P-solubilizing fungi from Paraty, Rio de Janeiro, Brazil (PSF 7, 9, 20, 21 and 22) and from Granada, Spain (A. niger and Y. lipolytica). (Lower-case letters compare PSF treatments by the Scott-Knott test $(p \leq 0.05)$.

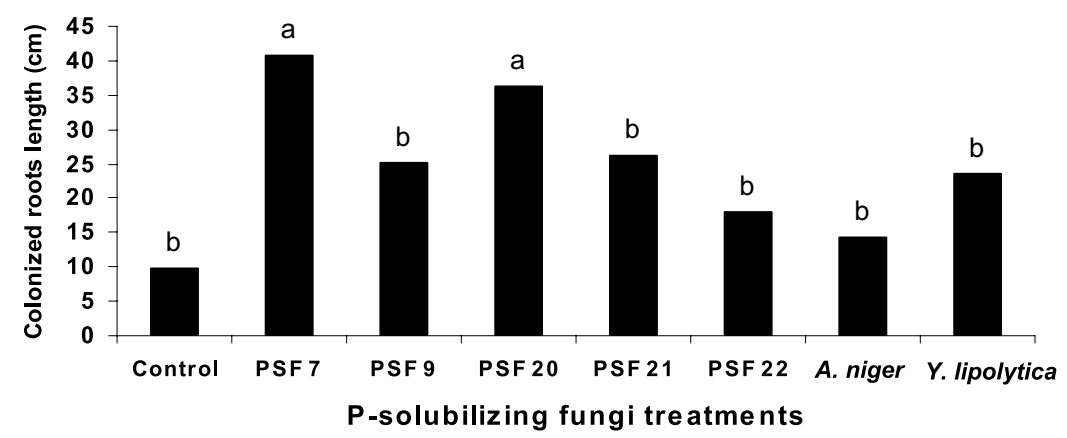

Fig. 4 - Mycorrhizal colonized root length of clover inoculated with P-solubilizing fungi from Paraty, Rio de Janeiro, Brazil (PSF 7, 9, 20, 21 and 22) and from Granada, Spain (A. niger and Y. lipolytica). (Lower-case letters compare PSF treatments by the Scott-Knott test $(p \leq 0.05)$.

\section{ACKNOWLEDGMENTS}

To Coordenação de Aperfeiçoamento de Pessoal de Nível Superior/ Programa de Doutorado com Estágio no Exterior (CAPES/PDEE) for the scholarship grant.

\section{RESUMO}

Este estudo avaliou o sinergismo entre diversos isolados de fungos solubilizadores de fosfato e micorrízicos arbusculares para beneficiar o crescimento de trevo (Trifolium pratense) na presença de apatita de Araxá. A cultura foi semeada diretamente em potes plásticos com $300 \mathrm{~g}$ de substrato esterilizado formado por areia lavada, vermiculita e sepiolita 1:1:1 (v:v:v) e cultivada em câmara climática. O substrato foi fertilizado com $3 \mathrm{~g} \mathrm{~L}^{-1}$ de apatita de Araxá. O experimento foi instalado em delineamento completamente casualizado, esquema fatorial $8 \times 2$ (oito tratamentos de inoculação de fungos solubilizadores de fosfato com ou sem fungos micorrízicos arbus- culares) e quatro repetições. Os tratamentos de fungos solubilizadores de fosfato consistiram em cinco isolados brasileiros de fungos solubilizadores de fosfato (FSF 7, 9, 20, 21 e 22), dois isolados procedentes da Espanha (Aspergillus niger e a levedura Yarowia lipolytica) e o controle (tratamento não inoculado). A maior taxa de crescimento da cultura foi obtida quando Aspergillus niger e FSF 21 foram co-inoculados com fungos micorrízicos arbusculares. Aspergillus niger, FSF 7 e o FSF 21 foram os isolados mais efetivos para incrementar o crescimento de trevo na presença de fungos micorrízicos arbusculares. A maior taxa de colonização micorrízica resultou em alta taxa de crescimento de trevo na maioria dos tratamentos com fungos solubilizadores de fosfato. O isolado FSF 7 foi o melhor para favorecer o estabelecimento das simbioses com fungos micorrízicos e com rizóbio.

Palavras-chave: apatita de Araxá, solubilização de fosfato, co-inoculação, promoção do crescimento vegetal, rizosfera. 


\section{REFERENCES}

Arshad M And Frankenberger WT JR. 1998. Plant growth-regulating substances in the rhizosphere: microbial production and functions. Adv Agron 62: 46-151.

Barea JM, Azcón-Aguilar C And Azcón R. 1997. Interactions between mycorrhizal fungi and rhizosphere microorganisms within the context of sustainable soilplant systems. In: GANGE AC AND BROWN VK (Eds), Multitrophic interactions in terrestrial systems. Cambridge: Blackwell Science, Cambridge, UK, p. 65-77.

BERINGER JE. 1974. R factor transfer in Rhizobium leguminosarum. J Gen Microb 84: 188-198.

Cabello M, Irrazabal G, Bucsinszky am, SaparRAT M AND SCHALAMUKS. 2005. Effect of an arbuscular mycorrhizal fungus, Glomus mosseae, and a rockphosphate-solubilizing fungus, Penicillium thomii, on Mentha piperita growth in a soilless medium. J Basic Microbiol 45: 182-189.

EL-Azouni IM. 2008. Effect of phosphate solubilizing fungi on growth and nutrient uptake of soybean (Glycine max L.) plants. J Appl Sci Res 4: 592-598.

Fracchia S, Sampedro I, Scervino JM, Garcia-RoMERA I, OCAMPO JA AND GODEAS A. 2004. Influence of saprobe fungi and their exudates on arbuscular mycorrhizal symbiosis. Symbiosis 36: 169-182.

Giovannetti M And Mosse B. 1980. An evaluation of techniques for measuring vesicular-arbuscular mycorrhizal infection in roots. N Phytol 84: 489-500.

Hewitt EJ. 1966. Sand and water culture methods used in the studies of plant nutrition. In: TECHNICAL COMMUNICATIONS. Commonwealth Agricultural Bureau, London, p. $430-434$.

Kumar V, Punia SS, LaKshminarayana K AND NaRULA N. 1999. Effect of phosphate solubilizing analogue resistant mutants of Azotobacter chroococcum on sorghum. Ind J Agric Sci 69: 198-200.

Medina A, Vassilev N, Alguacil MM, Roldán A And AzCÓN R. 2004. Increased plant growth, nutrient uptake, and soil enzymatic activities in a desertified Mediterranean soil amended with treated residues and inoculated with native mycorrhizal fungi and a plant growth-promoting yeast. Soil Sci 169: 260-270.

NGUYEN C, YAN W, LE TACON F AND LAPEYRIE F. 1992. Genetic variability of phosphate solubilizing activity by monocaryotic and dicaryotic mycelia of the ectomycorrhizal fungus Laccaria bicolor (Maire) P.D. Orton. P1 Soil 143: 193-199.
OMAR SA. 1998. The role of rock-phosphate-solubilizing fungi and vesicular-arbuscular mycorrhiza (VAM) in growth of wheat plants fertilized with rock phosphate. W J Microbiol Biotech 14: 211-218.

Peix A, Mateos PF, Rodríguez-Barrueco C, MarTinez-Molina E AND VelazQuez E. 2001. Growth promotion of common bean (Phaseolus vulgaris L.) by a strain of Burkholderia cepacia under growth chamber conditions. Soil Biol Biochem 33: 1927-1935.

RAVNSKov S, LARSEN J, OLSSON PA AND JAKOBSEN I. 1999. Effects of various organic compounds on growth and phosphorus uptake of an arbuscular mycorrhizal fungus. N Phytol 141: 517-524.

Reyes I, Bernier L AND ANTOUN H. 2002. Rock phosphate solubilization and colonization of maize rhizosphere by wild and genetically modified strains of Penicillium rugulosum. Microb Ecol 44: 39-48.

RICHARDSON AE. 2001. Prospects for using soil microorganisms to improve the acquisition of phosphorus by plants. Aust J P1 Physiol 28: 897-906.

Rodríguez R, VASSILEV N AND AzCón R. 1999. Increases in growth and nutrient uptake of alfalfa grown in soil amended with microbially-treated sugar beet waste. Appl Soil Ecol 11: 9-15.

Silva Filho GN, Narloch C AND Scharf R. 2002. Solubilização de fosfatos naturais por microrganismos isolados de cultivos de Pinus e Eucalyptus de Santa Catarina. Pesq Agrop Bras 37: 847-854.

Sylvester-Bradley R, AskaWA N, Latorraca S, Magalhães FMM, Oliveira LA AND PEREIRA RM. 1982. Levantamento quantitativo de microrganismos solubilizadores de fosfato na rizosfera de gramíneas e leguminosas forrageiras na Amazônia. Acta Amaz 12: 12-22.

Souchie EL, AzCón R, BAREA JM, SAGgin-Júnior OJ AND SILVA EMR. 2005. Solubilização de fosfatos em meios sólido e líquido por bactérias e fungos do solo. Pesq Agrop Bras 40: 1149-1152.

Souchie EL, SAGgin-JÚNior OJ, Silva EMR, CAMPELLO EFC, AzCón R AND BAREA JM. 2006. Communities of P-solubilizing bacteria, fungi and arbuscular mycorrhizal fungi in grass pasture and secondary forest of Paraty, RJ-Brazil. An Acad Bras Cienc 78: 1-11.

TENNANT D. 1975. A test modified line intersect method estimating root length. J Ecol 63: 995-1001.

VAldenegro M, BAREA JM AND AzCón R. 2001. Influence of arbuscular mycorrhizal fungi, Rhizobium meliloti strains and PGPR inoculation on the growth of Medicago arborea used as model legume for revegetation and 
biological reactivation in a semi-arid Mediterranean area. Pl Growth Reg 34: 233-240.

Vassilev N, Vassileva M, Azcón R And Medina A. 2001. Preparation of gelentrapped mycorrhizal inoculum in the presence or absence of Yarowia lipolytica. Biotech Lett 23: 907-909.

Vassileva M, Vassilev N And Azcón R. 1998. Rock phosphate solubilization by Aspergillus niger on olive cake-based medium and its further application in soilplant system. W J Microb Biotech, 14: 281-284.

VAssileva M, Azcón R, BAREa JM And VAssilev N. 2000. Rock phosphate solubilization by free and encapsulated cells of Yarowia lipolytica. Proc Biochem 35: 693 697.
WAHID OA AND MEHANA TA. 2000. Impact of phosphatesolubilizing fungi on the yield and phosphorus-uptake by wheat and faba bean plants. Microb Res 155: 221-227.

Whitelaw MA, Harden TJ ANd Bender GL. 1997. Plant growth promotion of wheat inoculated with Penicillium radicum sp. nov. Aust J Soil Sci 35: 291-300.

ZAidi A, Khan S AND AAMIL M. 2004. Bioassociative effect of rhizospheric microorganisms on growth, yield, and nutrient uptake of greengram. J P1 Nutr 27: 601-612. 